RESEARCH ARTICLE

\title{
Genetic Analysis on Yield and Yield Components Traits in the Segregating Populations of Blackgram[Vigna mungo (L.) Hepper]
}

\author{
Ragul $\mathbf{S}^{1,2}$, Manivannan $\mathbf{N}^{2 *}$, lyanar $\mathbf{K}^{3}$, Ganapathy $\mathbf{N}^{4}$ and Karthikeyan $\mathbf{G}^{5}$ \\ ${ }^{1}$ National Pulses Research Center, Tamil Nadu Agricultural University, Vamban-622303, \\ ${ }^{2}$ Centre for Plant Breeding and Genetics, Tamil Nadu Agricultural University, Coimbatore - 641003. \\ ${ }^{3}$ Department of Millets, Tamil Nadu Agricultural University, Coimbatore - 641003. \\ ${ }^{4}$ Department of Agricultural Entomology, Tamil Nadu Agricultural University, Coimbatore - 641003 \\ ${ }^{5}$ Department of Plant Pathology, Tamil Nadu Agricultural University, Coimbatore - 641003
}

\begin{abstract}
The magnitude of variability and association among various traits in $\mathrm{F}_{2}$ populations of three crosses viz., MDU 1 x TU68, VBN6 x TU68, and VBN8 $x$ TU68 of blackgram were studied. The experiment was conducted the National Pulses Research Centre, Vamban, during Rabi 2019. The genotypic coefficient of variability was lower than the values of phenotypic coefficient of variability, which revealed the influence of the environment in deciding the expression of these populations. The traits viz., plant height, number of branches per plant, number of clusters per plant, number of pods per plant, and seed yield per plant has recorded high heritability and high genetic advance as per cent of mean for the majority of the crosses. It indicated that these traits were less influenced by the environment and possessed with high magnitude of genetic variability. Association studies revealed that the traits viz., number of clusters per plant, and number of pods per plant in all the three crosses recorded significant and positive association with seed yield per plant. Hence, based on the present investigation, it can be concluded that the number of clusters per plant and number of pods per plant should be given due importance in framing the selection indices for seed yield improvement in blackgram. However, separate selection indices are required for each population as the association of traits differs among populations.
\end{abstract}

Keywords: Blackgram; Segregating populations; Variability; Correlation; Yield traits.

\section{INTRODUCTION}

Pulses are the principal source of dietary protein among vegetarians. It is an integral part of the daily diet because of itshigh protein content and good amino-acid balance. On account of the balanced aminoacid composition of cereals and protein blend, which matches with the milk protein, pulses are often called the life line of human beings. Among the pulses,blackgram[Vigna mungo (L.) Hepper] is an important food legume crop of the Indian subcontinent. It is an important short-duration crop and is widely cultivated in India. It gives us an excellent source of easily digestible good quality protein and the ability to restore soil fertility through symbiotic nitrogen fixation. Seeds are highly nutritious with protein (24-26\%), carbohydrates $(60 \%)$, fat (1.5\%), minerals, amino acids, and vitamins.In India, the area that comes under blackgram is about 4.50 million hectares with a production of
2.83 million tonnes (Project coordinator's report, 2019). However, the global productivity of pulses in general and blackgram in particular is very low as compared to cereals. One amongst many reasons for the low productivity of blackgram is the low yield potential of the present-day cultivars. Lesser variability is one factors responsible for the poor progress made in the breeding programme of pulse crops.Crop improvement programmes can improve productivity in various aspects. The basic need for any crop improvement programme is variation in a population. The knowledge on inheritance can be understood by the variability studies of various quantitative and yield traits through the estimation of variances namely, genotypic coefficients of variations, phenotypic coefficients of variations, heritability in per cent, and genetic advance as per cent of mean, which help to frame the effective crop improvement programme (Reni et al., 2013). 
Association of yield components is very important for an efficient selection programme. The association analysis provides information on the correlation of various traits towards yield and its components, respectively. With this background, the present study was carried out to assess variability and association studies in three $F_{2}$ populations of blackgram.

\section{MATERIALS AND METHOD}

The experiment was performed at the National Pulses Research center (NPRC), Tamil Nadu Agricultural University, Vamban during Rabi 2019. The experimental material consists of $F_{2}$ generation obtained from three crosses of blackgram,i.e., MDU 1 x TU68 (cross 1), VBN6 x TU68 (cross 2), and VBN8 $x$ TU68 (cross 3). The variety, MDU 1 is a high yielder but susceptible to MYMV was released from Agriculture College and Research Institute, Tamil Nadu Agricultural University, Madurai for commercial cultivation. VBN 6 and VBN 8 were released from National Pulses Research Centre, Tamil Nadu Agricultural University, Vamban. The genotype TU 68 was developed from the cross TU 94-2 x Vigna mungo var. silvestris by Bhabha Atomic Research Centre, Trombay. TU 68 is a donor for bruchid resistance. All three parents, viz., VBN 6, VBN 8, and TU 68 have MYMV disease resistance. Observations were recorded for days to flowering, plant height $(\mathrm{cm})$, number of branches per plant, number of clusters per plant, number of pods per cluster, number of pods per plant, pod length (cm), number of seeds per pod, 100-seed weight (g) and seed yield per plant (g). Observations were recorded on all the single plants of $F_{2}$ generation of three cross combinations along with their parents. Various genetic parameters like PCV, GCV, heritability and genetic advance as per cent of mean were worked out by adopting the methods given by Johnson et al. (1955). In addition, skewness and kurtosis were also worked out as per the standard method. A simple correlation between seed yield and its component traits and among themselves wasworked out as per the method suggested by Johnson et al. (1955). The data were analyzed using the statistical software TNAUSTAT statistical package (Manivannan, 2014).

\section{RESULTS AND DISCUSSION}

PCV and GCV are essential in understanding the nature and magnitude of variability present in the population due to the genetic and non-genetic causes. As GCV provides the total amount of heritable portion in the total variability, PCV also includes the environmental variability.The mean and the variability parameters such as phenotypic coefficient of variation (PCV), genotypic coefficient of variation (GCV), heritability $\left(\mathrm{h}^{2}\right)$, and genetic advance as per cent of mean (GAM) for the $F_{2}$ populations of three crosses viz., MDU 1 x TU 68 (C1), VBN 6 X TU 68 (C2) and VBN $8 \times$ TU 68 (C3) are presented in the Table. 1. Mean performances among the crosses of blackgram for various traits showed that majority of the traits has shown average performances in the $F_{2}$ population of the various crosses within the parental range except fora number of pods per plant, which recorded higher performances than the parent, i.e., $P_{1}$ and $P_{2}$ among the crosses. The traits number of clusters per plant and pod length in the $\mathrm{F}_{2}$ generation of MDU1 x TU68 cross has shown higher mean comparing the parental generations. In VBN6 x TU68 cross, the traits number of pods per cluster and seed yield per plant haverecorded higher mean effects than the parents. The trait number of branches per plant and seed yield per plant have recorded higher mean effects in the $F_{2}$ population over the parents in the cross VBN8 x TU68.

The variability results indicated that the estimates of the phenotypic coefficient of variation were higher than the genotypic coefficient of variation for all the characters studied indicating the environmental influence over the traits. The trait seed yield per plant recorded high PCV and GCV for all the crosses involved in the study.Similarly, Thirumalai and Murugan (2020) and Sathees et al. (2019) recorded higher PCV and GCV for seed yield per plant in their study. Days to flowering recorded low PCV and GCV for all the crosses. Plant height recorded high PCV with moderate GCV for all the crosses except VBN6 $x$ TU68 cross which recorded moderate PCV and GCV for the trait. Similar results were given by Punia et al. (2014). High PCV and GCV were observed for the traits viz., number of branches per plant, number of clusters per plant, and number of pods per plant in the crosses VBN 6 x TU 68 and VBN 8 x TU 68. Similar results were given by Ramya et al., (2014), Gowsalya et al.(2017) and Sushmitharaj et al.(2018). However, these traits recorded high PCV with moderate GCV in the cross MDU $1 \times$ TU 68. Similar results were reported by Bishnoi et al.(2017). Similarly,Usharani and Kumar (2016) reported moderate GCV for these traits in their study. High to moderate PCV and GCV ve recorded the traits number of pods per cluster, pod length, a number of seeds per pod and 100seed weight among all the crosses. Similar results were also given by Neelavathi and Govindarasu (2010), Kumar et al.(2015), Singh et al.(2014) and Sushmitharaj et al. (2018).

Heritability and genetic advance as per cent of the mean isessential for any population to know the magnitude of inheritance of traits and helpful in formulating the selection procedure. High heritability coupled with low genetic advance indicates the presence of non -additive gene action and selection for such traits may not be rewarding. 
Table 1 .Variability parametersin $F_{2}$ population among various crosses of blackgramfor yield and yield components traits.

\begin{tabular}{|c|c|c|c|c|c|c|c|c|c|c|}
\hline \multirow{2}{*}{ Characters } & \multirow{2}{*}{ ญू } & \multicolumn{3}{|c|}{ MEAN } & \multirow{2}{*}{ PCV (\%) } & \multirow{2}{*}{ GCV (\%) } & \multirow{2}{*}{$h^{2}(\%)$} & \multirow{2}{*}{ GAM (\%) } & \multirow{2}{*}{ Skewness } & \multirow{2}{*}{ Kurtosis } \\
\hline & & $\mathbf{P}_{1}$ & $\mathbf{P}_{2}$ & $\mathbf{F}_{2}$ & & & & & & \\
\hline \multirow[t]{3}{*}{ Days to flowering } & $\mathrm{C} 1$ & 36.15 & 26.00 & 32.26 & 9.37 & 8.39 & 80.15 & 16.30 & 0.28 & -0.65 \\
\hline & $\mathrm{C} 2$ & 34.20 & 26.05 & 31.17 & 9.88 & 9.05 & 83.86 & 17.98 & -0.43 & -0.53 \\
\hline & C3 & 34.30 & 25.46 & 30.93 & 10.25 & 9.38 & 83.89 & 18.65 & -0.29 & -0.68 \\
\hline \multirow[t]{3}{*}{ Plant height $(\mathrm{cm})$} & $\mathrm{C} 1$ & 39.00 & 21.61 & 24.39 & 20.13 & 11.66 & 33.54 & 14.65 & $0.85 * *$ & 0.81 \\
\hline & $\mathrm{C} 2$ & 28.80 & 24.70 & 25.09 & 19.70 & 15.77 & 64.07 & 27.38 & -0.15 & 0.77 \\
\hline & C3 & 24.20 & 21.62 & 19.84 & 25.18 & 14.03 & 31.04 & 16.96 & 0.40 & -0.57 \\
\hline \multirow{3}{*}{$\begin{array}{l}\text { No. of branches per } \\
\text { plant }\end{array}$} & $\mathrm{C} 1$ & 2.00 & 3.50 & 2.19 & 33.19 & 11.73 & 12.50 & 9.00 & $0.48 *$ & 0.35 \\
\hline & $\mathrm{C} 2$ & 2.25 & 3.85 & 2.47 & 43.69 & 30.75 & 49.54 & 46.97 & $1.19 * *$ & $2.3 * *$ \\
\hline & C3 & 2.25 & 2.77 & 3.02 & 45.07 & 38.99 & 74.86 & 73.21 & $0.80 * *$ & 0.21 \\
\hline \multirow{3}{*}{$\begin{array}{l}\text { No. of clusters per } \\
\text { plant }\end{array}$} & $\mathrm{C} 1$ & 6.20 & 6.67 & 8.29 & 28.77 & 16.45 & 32.71 & 20.42 & $1.23 * *$ & $4.06 * *$ \\
\hline & $\mathrm{C} 2$ & 7.35 & 12.45 & 10.72 & 38.76 & 33.39 & 74.18 & 62.40 & $1.28 * *$ & $1.96 * *$ \\
\hline & $\mathrm{C} 3$ & 7.80 & 10.15 & 10.05 & 35.29 & 25.15 & 50.79 & 38.89 & $0.66 *$ & -0.22 \\
\hline \multirow{3}{*}{$\begin{array}{l}\text { No. of pods per } \\
\text { cluster }\end{array}$} & $\mathrm{C} 1$ & 3.40 & 3.11 & 3.20 & 19.09 & 8.69 & 20.72 & 8.58 & $0.51 *$ & 0.85 \\
\hline & $\mathrm{C} 2$ & 2.75 & 2.35 & 3.02 & 23.83 & 18.14 & 57.95 & 29.97 & -0.17 & -0.66 \\
\hline & C3 & 2.70 & 2.38 & 2.29 & 30.69 & 22.10 & 51.85 & 34.53 & -0.28 & -0.61 \\
\hline \multirow[t]{3}{*}{ No. of pods per plant } & $\mathrm{C} 1$ & 20.75 & 20.11 & 26.11 & 31.49 & 13.95 & 19.64 & 13.42 & $0.57^{*}$ & 0.44 \\
\hline & $\mathrm{C} 2$ & 23.70 & 28.35 & 31.12 & 45.91 & 29.11 & 40.19 & 40.04 & $1.57 * *$ & 2.91 \\
\hline & $\mathrm{C} 3$ & 19.65 & 21.92 & 22.72 & 47.66 & 27.42 & 33.09 & 34.23 & $0.61 *$ & -0.19 \\
\hline \multirow[t]{3}{*}{ Pod length (cm) } & $\mathrm{C} 1$ & 4.72 & 4.23 & 5.09 & 11.68 & 8.57 & 53.74 & 13.63 & 0.25 & -0.32 \\
\hline & $\mathrm{C} 2$ & 5.54 & 4.92 & 4.86 & 19.55 & 17.40 & 79.18 & 33.60 & -0.43 & -1.04 \\
\hline & C3 & 5.52 & 4.91 & 5.34 & 8.19 & 3.84 & 21.99 & 3.91 & -0.39 & $1.55 * *$ \\
\hline \multirow[t]{3}{*}{ No. of seeds per pod } & $\mathrm{C} 1$ & 6.95 & 5.44 & 6.36 & 15.82 & 8.62 & 29.66 & 10.18 & $-0.73 * *$ & 0.65 \\
\hline & $\mathrm{C} 2$ & 6.55 & 5.45 & 6.81 & 10.62 & 7.53 & 50.23 & 11.58 & 0.18 & -0.81 \\
\hline & $\mathrm{C} 3$ & 6.55 & 5.85 & 6.06 & 10.30 & 3.79 & 13.51 & 3.02 & -0.34 & 0.76 \\
\hline \multirow[t]{3}{*}{ 100- seed weight $(\mathrm{g})$} & $\mathrm{C} 1$ & 3.94 & 2.56 & 2.85 & 14.96 & 8.29 & 30.74 & 9.98 & $0.61 * *$ & 0.03 \\
\hline & $\mathrm{C} 2$ & 3.45 & 2.77 & 2.78 & 12.68 & 5.93 & 21.86 & 6.01 & $1.43 * *$ & $3.00 * *$ \\
\hline & $\mathrm{C} 3$ & 3.80 & 2.56 & 3.11 & 28.35 & 26.50 & 87.37 & 53.74 & $4.21 * *$ & $26.59 * *$ \\
\hline \multirow{3}{*}{$\begin{array}{l}\text { Seed yield per plant } \\
\text { (g) }\end{array}$} & $\mathrm{C} 1$ & 5.17 & 3.65 & 4.48 & 41.64 & 36.82 & 78.17 & 70.64 & $3.36 * *$ & $15.84 * *$ \\
\hline & $\mathrm{C} 2$ & 5.02 & 4.46 & 5.19 & 45.84 & 38.07 & 68.96 & 68.60 & $1.52 * *$ & $2.10 * *$ \\
\hline & C3 & 4.94 & 3.44 & 5.16 & 43.78 & 34.46 & 61.97 & 58.87 & $1.27 * *$ & $1.55 * *$ \\
\hline
\end{tabular}

*,** Significant at 5\%and 1\% respectively. C1=MDU 1 x TU 68; C2=VBN 6 × TU 68; C3=VBN 8 x TU 68.

Note: PCV= Phenotypic coefficient of variation; GCV = Genotypic coefficient of Variation; $h^{2}=$ Heritability (\%); GAM = Genetic advance as per cent of mean

High heritability along with high genetic advance and low heritability accompanied with high genetic advance indicate the presence of additive gene effect. Selection based on the high heritability with high genetic advance rewards good results in the improvement for such traits due to the presence of an additive type of gene action. Low heritability with low genetic advance suggests that the environment highly affects the trait. In such instances, selection may be ineffective. Days to flowering recorded high heritability with moderate GAM for all four crosses. Plant height recorded high heritability with high GAM for the cross VBN 6 x TU 68. Crosses MDU1x TU 68 and VBN 8 x TU 68 recorded moderate heritability and moderate GAM for plant height. Similar results were recorded by Panigrahi et al.(2014) and 
Sushmitharaj et al. (2018) for plant height. High heritability with high GAM was observed for the trait number of branches per plant for the cross VBN 8 $x$ TU 68. Whereasthe remaining crosses recorded moderate to low heritability and GAM for a number of branches per plant (Punia et al., 2014; Kumar et al., 2015). The number of clusters per plant recorded high heritability along with high GAM for the cross VBN6 x TU 68 (Gowsalya et al., 2017). The remaining crosses recorded moderate heritability and high GAM fora number of clusters per plant. Similar results were given by Kumar et al.(2015) and Arulbalachandran et al. (2010). The trait number of pods per cluster had moderate heritability and high GAM among the crosses of VBN6 x TU 68 and
VBN 8x TU 68.Cross MDU 1 x TU 68 recorded low heritability with low GAM for this trait. A number of pods per plant recorded moderate heritability and high GAM in the crosses VBN6 $x$ TU 68 and VBN 8x TU 68. However, MDU $1 \times$ TU 68 recorded low heritability with moderate GAM for the trait. Similar results were also observed by Sushmitharaj et al.(2018) and Bishnoi et al.(2017). Pod length, number of seeds per pod, and 100 - seed weight recorded high to low ranges of heritability and GAM for all crosses. The trait seed yield per plant recorded high heritability and high GAM for all the crosses. Similar results were also recorded by Gowsalya et al.(2017), Hemalatha et al.(2017), Sushmitharaj et al.(2018) and Anuradha et al. (2020).

Table 2.Simple correlation between single plant yield and yield component traits among $F_{2}$ generations of various crosses in blackgram

\begin{tabular}{|c|c|c|c|c|c|c|c|c|c|c|}
\hline Characters & $\begin{array}{l}\text { ô } \\
\text { ठ̀ }\end{array}$ & 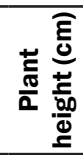 & 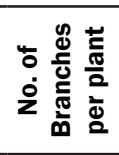 & 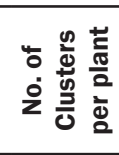 & 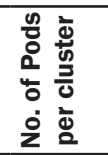 & 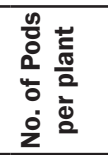 & 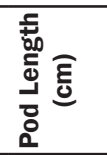 & 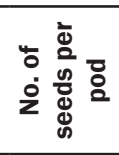 & 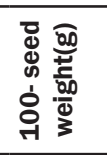 & 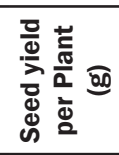 \\
\hline \multirow{3}{*}{$\begin{array}{l}\text { Days to } \\
\text { Flowering }\end{array}$} & $\mathrm{C} 1$ & -0.01 & -0.09 & -0.04 & 0.00 & -0.05 & 0.03 & $0.14 *$ & $0.23 * *$ & 0.15 \\
\hline & $\mathrm{C} 2$ & 0.06 & 0.02 & 0.01 & -0.14 & 0.02 & 0.12 & -0.01 & 0.06 & 0.09 \\
\hline & C3 & 0.10 & -0.03 & 0.02 & -0.04 & 0.04 & 0.17 & 0.08 & 0.19 & 0.01 \\
\hline \multirow{3}{*}{$\begin{array}{l}\text { Plant height } \\
\text { (cm) }\end{array}$} & $\mathrm{C} 1$ & & $0.23 *$ & $0.23 * *$ & 0.09 & 0.14 & 0.07 & 0.10 & 0.11 & 0.05 \\
\hline & $\mathrm{C} 2$ & & $0.41 * *$ & $0.48 * *$ & 0.15 & $0.54 * *$ & 0.15 & $0.23 * *$ & -0.03 & $0.50 * *$ \\
\hline & C3 & & 0.24 * & $0.22 *$ & 0.11 & $0.32 * *$ & 0.17 & $0.22 *$ & 0.01 & $0.25 *$ \\
\hline \multirow{3}{*}{$\begin{array}{l}\text { No. of } \\
\text { Branches per } \\
\text { plant }\end{array}$} & $\mathrm{C} 1$ & & & $0.36 * *$ & 0.08 & $0.24 * *$ & 0.11 & 0.06 & 0.16 & 0.12 \\
\hline & $\mathrm{C} 2$ & & & $0.67 * *$ & 0.07 & $0.61 * *$ & 0.04 & $0.16 *$ & -0.07 & $0.61 * *$ \\
\hline & C3 & & & $0.55 * *$ & 0.09 & $0.31 * *$ & -0.03 & 0.00 & 0.21 & $0.35 * *$ \\
\hline \multirow{3}{*}{$\begin{array}{l}\text { No. of Clusters } \\
\text { per plant }\end{array}$} & $\mathrm{C} 1$ & & & & 0.03 & $0.74 * *$ & -0.05 & 0.04 & -0.17 & $0.37 * *$ \\
\hline & $\mathrm{C} 2$ & & & & 0.05 & $0.86 * *$ & 0.17 & $0.18 *$ & -0.07 & $0.73 * *$ \\
\hline & C3 & & & & $0.44 * *$ & $0.79 * *$ & 0.13 & 0.19 & -0.05 & $0.55 * *$ \\
\hline \multirow{3}{*}{$\begin{array}{l}\text { No. of Pods per } \\
\text { cluster }\end{array}$} & $\mathrm{C} 1$ & & & & & $0.32 * *$ & -0.04 & -0.04 & -0.05 & 0.11 \\
\hline & $\mathrm{C} 2$ & & & & & $0.33 * *$ & $-0.32 * *$ & $0.18 *$ & -0.15 & 0.15 \\
\hline & C3 & & & & & $0.75^{* *}$ & 0.10 & 0.10 & -0.10 & $0.39 * *$ \\
\hline \multirow{3}{*}{$\begin{array}{l}\text { No. of Pods per } \\
\text { plant }\end{array}$} & $\mathrm{C} 1$ & & & & & & -0.10 & 0.01 & $-0.22 *$ & $0.47 * *$ \\
\hline & $\mathrm{C} 2$ & & & & & & 0.03 & $0.25 * *$ & -0.04 & $0.76 * *$ \\
\hline & C3 & & & & & & 0.16 & 0.18 & -0.13 & $0.61 * *$ \\
\hline \multirow{3}{*}{$\begin{array}{l}\text { Pod Length } \\
(\mathrm{cm})\end{array}$} & $\mathrm{C} 1$ & & & & & & & $0.61 * *$ & $0.18 *$ & 0.02 \\
\hline & $\mathrm{C} 2$ & & & & & & & $0.23 * *$ & 0.08 & $0.23 * *$ \\
\hline & C3 & & & & & & & $0.70 * *$ & 0.16 & 0.19 \\
\hline \multirow{3}{*}{$\begin{array}{l}\text { No. of seeds } \\
\text { per pod }\end{array}$} & $\mathrm{C} 1$ & & & & & & & & 0.01 & 0.17 \\
\hline & $\mathrm{C} 2$ & & & & & & & & -0.11 & $0.20 *$ \\
\hline & C3 & & & & & & & & 0.08 & 0.17 \\
\hline \multirow{3}{*}{$\begin{array}{l}100-\text { seed } \\
\text { weight(g) }\end{array}$} & $\mathrm{C} 1$ & & & & & & & & & $0.22 *$ \\
\hline & $\mathrm{C} 2$ & & & & & & & & & 0.15 \\
\hline & C3 & & & & & & & & & $0.28 * *$ \\
\hline
\end{tabular}

*,** Significant at 5\%and 1\% respectively.C1=MDU 1 x TU 68; C2=VBN 6 × TU 68; C3=VBN 8 × TU 68

$107|10-12| 4$ 
Among the $\mathrm{F}_{2}$ populations, noskewness / normal distribution was observed for days to flowering and pod length in all three crosses. The traits viz., number of branches per plant, number of clusters per plant, number of pods per plant, 100- seed weight and seed yield per plant recorded significant and positive skewness in all the three crosses indicates the lesser proportion of segregants with higher values for these traits. The remaining traits recorded positive to no skewness for all the three crosses involved. The traits days to flowering, plant height, number of pods per cluster, number of pods per plant, and number of seeds per pod had mesokurtic nature of distribution indicates the existence of moderate variability for these traits in all three crosses. The remaining traits recorded leptokurtic to mesokurtic nature of distribution among the three crosses indicated the narrow to moderate level of variability for these traits in all the crosses.

Simple correlations coefficients between seed yield per plant and its component characters and inter relationships among the different traits are presented in Table. 2. Seed yield per plant expressed significant and positive association with the traits studied viz., number of clusters per plant and number of pods per plant in all the three crosses. This result was in accordance with the findings of Kumar et al. (2013), Keerthiga et al.(2018) and Sushmitharaj et al.(2018). Plant height and a number of branches per plant have significant and positive association with seed yield per plant in all the cross except MDU $1 \times$ TU 68 cross. The trait number of pods per cluster had a significant and positive association with seed yield per plant in the VBN 8 x TU 68 cross combination only. The trait 100 - seed weight recorded a significant and positive association with seed yield per plant in the crosses MDU1 x TU 68 and VBN 8 x TU 68. Similar results were also given by Mehra et al. (2016), Singh et al. (2016), Rajasekhar et al.(2017) and Keerthiga et al.(2018).

\section{CONCLUSION}

Based on the results of the present investigation, it can be concluded that there was sufficient genetic variability in the segregating populations studied for all the characters. The traits viz., plant height, number of branches per plant, number of clusters per plant, number of pods per plant and seed yield per plant recorded high heritability along with high genetic advance as per cent of mean. Hence, these traits were less influenced by the environment and possess an additive type of gene action with high genetic variability. Hence, selection can be practiced for these traits in these populations. Based on association studies it can be concluded that a number of clusters per plant and number of pods per plant recorded significant and positive association with seed yield per plant. These traits also hadsignificant and positive correlation among them. Hence, these traits can be used as a selection index for the seed yield improvement programme in blackgram. However, separate selection indices are required for each population as the association of traits differs among populations.

\section{ACKNOWLEDGEMENTS\&FUNDING}

Authors acknowledge the help rendered by Mr. Arul Doss, Agricultural Supervisor, NPRC, Vamban in the trial. No funds were received for this research.

\section{Ethics statement:}

The author declares that the study performed is true with novelty in the interpretations.

\section{Originality and plagiarism}

The author declares that the stud has written based on the original works. The methods utilized were properly cited and acknowledged.

\section{Consent for publication}

All the authors agreed to publish the content.

\section{Conflicts of interest/Competing interests:}

The authors declare that the research was conducted in the absence of any commercial or financial relationships that could be construed as a potential conflict of interest.

\section{Author contribution:}

Experiments- SR,Guidance - NM, KI, NG and GK Writing original draft - SR, NM, KI, NG and GK Writing- reviewing \& editing - SR, NM

\section{REFERENCES}

Anonymous, 2019. AICRP MULLaRP- Project coordinator's report: Mungbean and urdbean. Indian Institute of Pulses Res, Kanpur, Pp 35-39

Anuradha, N., Patro, T. S. S. K., Triveni, U. and P. J. R. S. Rajkumar. 2020. Character association and variability studies in black gram advanced breeding lines. Journal of Pharmacognsy and Phytochemistry, 9(1): 1880-1882.

Arulbalachandran, D., Mullainathan, L., Velu, S. and C. Thilagavathi. 2010. Genetic variability, heritability and genetic advance of quantitative traits in black gram by effects of mutation in field trail. African J. Biotechnol.,9 (19): 2731-2735.

Bishnoi.,Anu., Priyanka Gupta., Meghawal, D. R, and G. M. Lal.2017. Evaluation of genetic variability and heritability in blackgram (Vignamungo(L.)Hepper) genotypes.J. Pharma. Phytochem.,6 (4): 493-496.

Dewey, D. R. and K. Lu.1959. A Correlation and PathCoefficient Analysis of Components of Crested Wheatgrass Seed Production.Agronomy J., 51(9), 515-518.

Gowsalya, P., Kumaresan, D., Packiaraj, D., and J. R. Bapu.2017.Genetic divergence in blackgram 
[Vignamungo(L) Hepper].Indian J. Agric. Res.,51(2).184-187.

Hemalatha.,Kondagari., Sapna, S. L. and M. L. Gabrial. 2017. Study on genetic variability and correlation in blackgram(VignamungoL. Hepper). J. Pharma. Phytochem., 6 (4): 674-676.

Johnson, H. W., Robinson, H. and R. Comstock.1955. Estimates of Genetic and Environmental Variability in Soybeans 1. Agronomy J., 47(7), 314-318.

Keerthiga, S., Sen, S., Pandya, H. R. and K. G. Modha. 2018. Correlation and path analysis in $F_{4}$ progenies of green gram [Vignaradiata(L.) Wilczek] for seed yield and its attributes.International J. Current Microbio. Appl. Sci.,7 (1):710-719.

Kumar., Sunil, B., Padmavathi, S., Prakash, M. and J. Ganesan.2003. Correlation and path analysis in black gram (VignamungoL. Hepper).Legume Res.,26 (1):75-76.

Kumar., Vijay, G., Vanaja, M., Jyothi Lakshmi, N. and M. Maheswari.2015. Studies on variability, heritability and genetic advance for quantitative traits in blackgram (Vignamungo(L.)Hepper).Agric. Res. J., 52 (4):28-31.

Kumar, K., Prasad, Y., Mishra, S., Pandey, S. and R. Kumar.2013. Study on genetic variability, correlation and path Analysis with grain yield and yield attributing traits in green gram [Vigna radiata (L) Wilczek]. The Bioscan, 8(4): 1551-1555.

Manivannan, N. 2014.TNAUSTAT- Statistical package. Retrieved from https://sites.google.com/site/ tnaustat.

Mehra.,Reena., Tikle. A. N., Ashok Saxena., Ashok Munjal, and M. Singh.2016. Correlation, pathcoefficient and genetic diversity in Blackgram (Vignamungo(L) Hepper). International Res. J. Plant Sci., 7 (1): 001-011.

Neelavathi, S. and R. Govindarasu. 2010. Analysis of variability and diversity in rice fallow blackgram [Vignamungo(L.) Hepper].Legume Res., 33 (3):206-210.

Panigrahi, K. K., Mohanty, A. and B. Baisakh.2014.Genetic divergence, variability and character association in landraces of blackgram (Vignamungo[L.] Hepper). Odisha.J. Crop. Weed., 10 (2):155-165.

Punia, S. S., Gautam, N. K., Baldev Ram., PreetiVerma., MeenakshiDheer., Jain, N. K., Koli, N. R., Rajesh
Mahavar. andV. S. Jat.2014. Genetic variability and correlation studies in urd bean (Vignamungo (L.)). Legume Res., 37 (6):580-584.

Rajasekhar.,Duddukur., Sapna S Lal. andM. L. Gabrial.2017. Character association and path analysis for seed yield \& its components in blackgram [Vignamungo(L.)Hepper]. Plant Archives.17 (1): 467-471.

Ramya, B., Nallathambi, G. and S. Ganeshram.2014. Genetic variability, heritability and genetic advance in induced mutagenesis blackgram (VignamungoL. Hepper). Plant Archives.14 (1): 139-141.

Reni.,Pushpa, Y., KoteswaraRao, Y., Satish, Y. and J. S. Babu.2013. Estimates of genetic parameters and path analysis in blackgram (Vignamungo(L.) Hepper). International J. Plant, Animal Environ. Sci., 3 (4): 231-234.

Sathees, N., Shoba, D., Saravanan, S., MerinapremKumari, S. and M. A. Pillai.2019.Studies on genetic variability, association and path coefficient analysis in black gram (Vignamungo L. Hepper). International J. Current Microbio. Appl. Sci., 8 (7) 1892-1899.

Singh., Awnindra, K., Gautam, R. K., Singh, P. K., Kumar, K., Kumar, N., Swain, S. and S. R Dam.2014. Estimation of genetic variability and association analysis in the indigenous landraces of Urdbean (VignamungoL. Hepper) of Andaman islands. Vegetos. 27 (1):113-122.

Singh., Monika., InduSwarup., Billore, M. and P. R. Chaudhari.2016. Association analysis of seed yield and its attributing traits in black gram [Vignamungo(L.)Hepper].Agric. Sci. Digest.36 (2);83-87.

Sushmitharaj, D. V., Shoba, D. and M. A. Pillai.2018. Genetic variability and correlation studies in black gram (Vignamungo [L.] hepper) with reference to YMV resistance. International J. Current Microbio. Appl. Sci.,6: 2849-2856.

Thirumalai, R. and Murugan, S. 2020 . Multivariate analysis in blackgram (Vignamungo (L.) hepper) genotypes for mungbean yellow mosaic virus (MYMV) resistance. Plant Archives, 20(1): 2473-2480.

Usharani, K. S, and C. R. A. Kumar.2016. Estimation of variability, heritability and genetic advance in mutant populations of blackgram (VignamungoL. Hepper). SABRAO J. Breed. Genet.,48 (3):258-265. 